\title{
A case based, combined LCA and S-ROI methodology for sustainable mining in the Suceava County, Romania
}

\section{Ruxandra Ionce $^{1 *}$ (i) , Iuliana Gabriela Breabăn ${ }^{1 *}$ (i)}

${ }^{1}$ Alexandru Ioan Cuza University of Iasi;

* Correspondence: ruxandra.ionce@gmail.com; iulianab2001@gmail.com

Keywords: copper ore; Mining Life Cycle, Sustainable Return on Investment

\begin{abstract}
LCA (Life Cycle Assessment) is a useful tool in decision-making for most businesses that opt for sustainability and offers the possibility to compare different products, processes, and value chain scenarios, both real and hypothetical. Coupled with S-ROI (Sustainable Return on Investment), the LCA has a great potential in using available data for existing mining sites in the North-East Region of Romania to assess the economic, social and environmental benefits of certain sustainability measures on a local and regional level. The article will explore this approach of combining the two methodologies: LCA (Life Cycle Assessment) and S-ROI (Sustainable Return on Investment), with necessary adjustments according to the characteristics of the local mining activities, to show key investment areas that can improve the value chain of copper exploitation and preparation in the mining perimeter Mănăila. The case of the copper mine in Mănăila offers a great opportunity to apply the current LICYMIN (Life Cycle of Mining) research and to use available Ecoinvent data for the copper ore by comparing the current value chain scenario with a proposed scenario that includes a different location for a mining ore preparation unit, closer to the quarry. The results will give an insight into the potential social and economic impact (the measure can translate into a higher local employment rate, better social stability, lower transportation costs, etc.) as well as the environmental impact (reduction of GHG emission, pollution, and energy efficiency) of the suggested changes.
\end{abstract}

\section{Introduction}

The mining industry is an important part of sustainable development (Mudd et al., 2020) in most countries, irrespective of their economic rank (e.g., mature, newly emerging or developing economies), despite of being generally regarded as an economic activity with sever negative impacts on the environment. When performed in a sustainable way, it can contribute to economic stability and generate wealth in undeveloped areas around the globe. Copper is one of the most widely available metals, its economic value being determined by its excellent properties: it is malleable and ductile, making it an exceptional conductor of heat and electricity while also being corrosion resistant and antimicrobial (Wiliams, PArker,. However, one of the most important aspects in regards its sustainable qualities, is the long life cycle which can be prolonged for an indefinite amount of times (Copper is $100 \%$ recyclable). The copper mining industry has been following a constant annual growth trend of about $3.2 \%$ per annum since 1900, reaching a total of 20.5 million tons in 2019 (Wiliams, Parker, 2010). 
Since the spread of the new COVID-19 virus, the world economy has been unprecedently tested, as many industrial branches have been slowed down or even shut down. However, the copper industry has been insignificantly affected: at a European level the extraction industry was reduced from 1,484,100 tons in 2019 to 1,568,400 tonnes in 2020 (a drop of only 16.63\%) with monthly production rates of 2020 already showing signs of recovery (Wiliams, Parker, 2010).

In the Suceava County the copper mining activity covers three sites (Figure 1): the Mănăila open quarry, the Preparation Unit Iacobeni (for the chemical and mechanical preparation of the mining ore in order to obtain copper and zinc concentrates) and the Oița quarry (factory tailing dump).

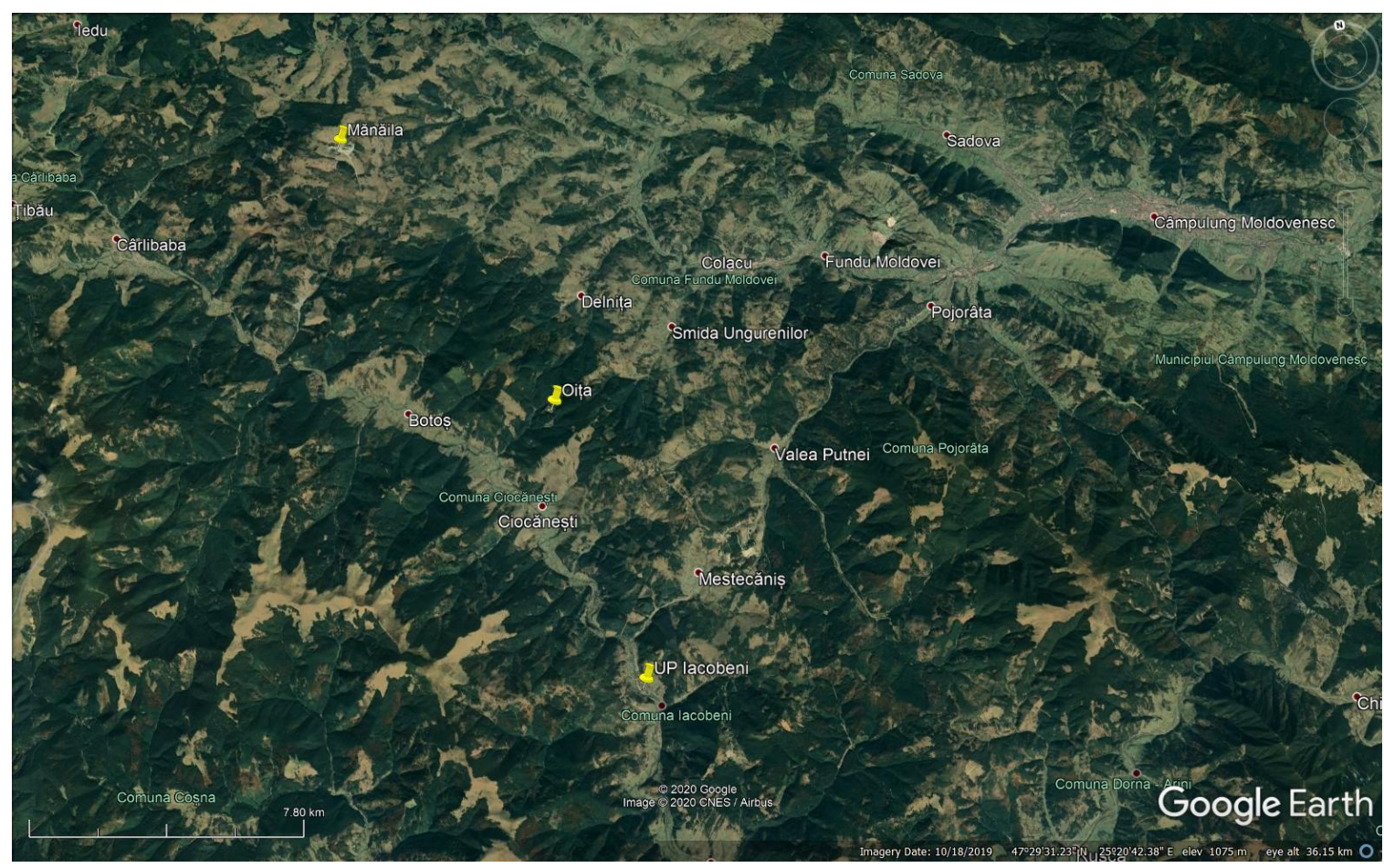

Figure 1. The placement of the copper ore mining sites, Suceava County

Considering the land/terrain configuration, the physical and chemical properties of the ore and the surrounding rocks, the spatial positioning of the copper ore lens, the descendant, open-pit quarry exploitation method was chosen by transporting the tailings on the dump built on the valley of the Bașca Creek. The mining perimeter is situated in the Crystalline Mesozoic Mountain Group of the North East Carpathians in the subdistrict of the Obcinele Bucovinei (Bukovinian Subcarpathians), the segment Obcina Mestecăniș. The Mănăila Quarry, situated in the Breaza Commune with access from the commune Cărlibaba along the valley of the Valea Seaca Creek (left-side tributary of the Bistrița Aurie River), occupying a surface of 22 ha and a production capacity projected at 70,000 t/yr (OUG195/2005).

The ore is processed in the Preparation Unit situated in Iacobeni, on the left bank of the River Bistrița. The mineralogical observations and analyses indicate the following preparation flux (OUG57/2007): 
- Crushing- performed on a two-stage technological line;

- Siloing- everything resulting from the grinding process is transported via specialised vehicles and dumped into a bunker type silo;

- Grinding- can be performed in two ways by using a ballmill or controlled separation through a hydrocyclon;

- Collective flotation $\mathrm{Cu}-\mathrm{Pb}-\mathrm{Zn}$. Due to the heavy contents and extractions, the collective flotation is performed with two batteries consisting of 22 flotation cells each. The flotation cells are of IPROMIN type, equipped with self-aeration;

- Flotation to separate $\mathrm{Cu}-\mathrm{Zn}$. The product undergoes a separation line consisting of 12 re-flotation cells;

- Enrichnening- filtration of the concentrates/ Smelting with fluxes and filtration of the concentrates.

The tailings resulted from the processing phase are then transported to the dumpthe Oița Quarry undergoes a technologic flux of concentrating- smelting- enricheningfiltration- drying (Autorizație de mediu no.221/2012), the final sludge having a humidity of $6.6 \%$. The sludge resulted from the waste-water treatment plant is also deposited in the Oița Quarry; this type of sludge has a humidity of $12 \%$. The deposit was designed having in mind the optimal waterproofing solutions and the elimination of all possible leacks outside of the mining perimeter, being equipped with a permanent monitoring system. The tailing dump is situated in the former Manganese quarry, in the Ciocănești Commune, in the median part of the Obcina Mestecănișului, along the course of the Oița Creek, a left-side tributary of the Bistrița Aurie River.

\section{Materials and Methods}

Even though copper can be entirely recyclable, only about $50 \%$ of the EU demand is covered by recycling (Soulier et al., 2018), mining continuing to be the most important source of copper. In the life cycle analysis of the copper products, the exploitation and preparation activities are the most important phases in terms of their overall impact on the environment and their negative social and economic consequences (even though these activities weigh low in the life cycle of the final product). Therefore, it is imperative to quantify the negative footprint of this segment and to find solutions to counterbalance or to mitigate the negative effects.

The LCA methodology (Life Cycle Assessment) is used in order to quantify the impact (in this case the carbon footprint) of a certain product or service, based on the international standards ISO 14040 și ISO 14044 (2006). The software used is LCA Calculator based on the integrated Ecoinvent database. Life Cycle Assessment Methodology is an integrated assessment method that offers a better understanding of the complex aspects of a product's or a service's environmental impact. LCA is generally considered, both in academia and in industrial planning, an indispensable tool to "provide support in better integrating environmental sustainability in decision making [...] evidence thereof is given in numerous cases developed by organizations at different levels" (Sonderegger et al., 2017).

Terminology used (Figure 2): 
- Manufacture: includes all raw materials, additional components and their assemblages used to assemble/build/produce the final product.

- Transport: includes the transport of raw materials, wastes and final product to the end client or retail etc.

- Use: includes all consumables (such as batteries, fuels, detergents etc.) and/or energy consumption (renewable or non-renewable) during the production or entire lifetime of the product.

- Disposal: greenhouse gas emissions in this phase are calculated depending on whether materials are recycled or not, disposed into a landfill, incinerated etc.

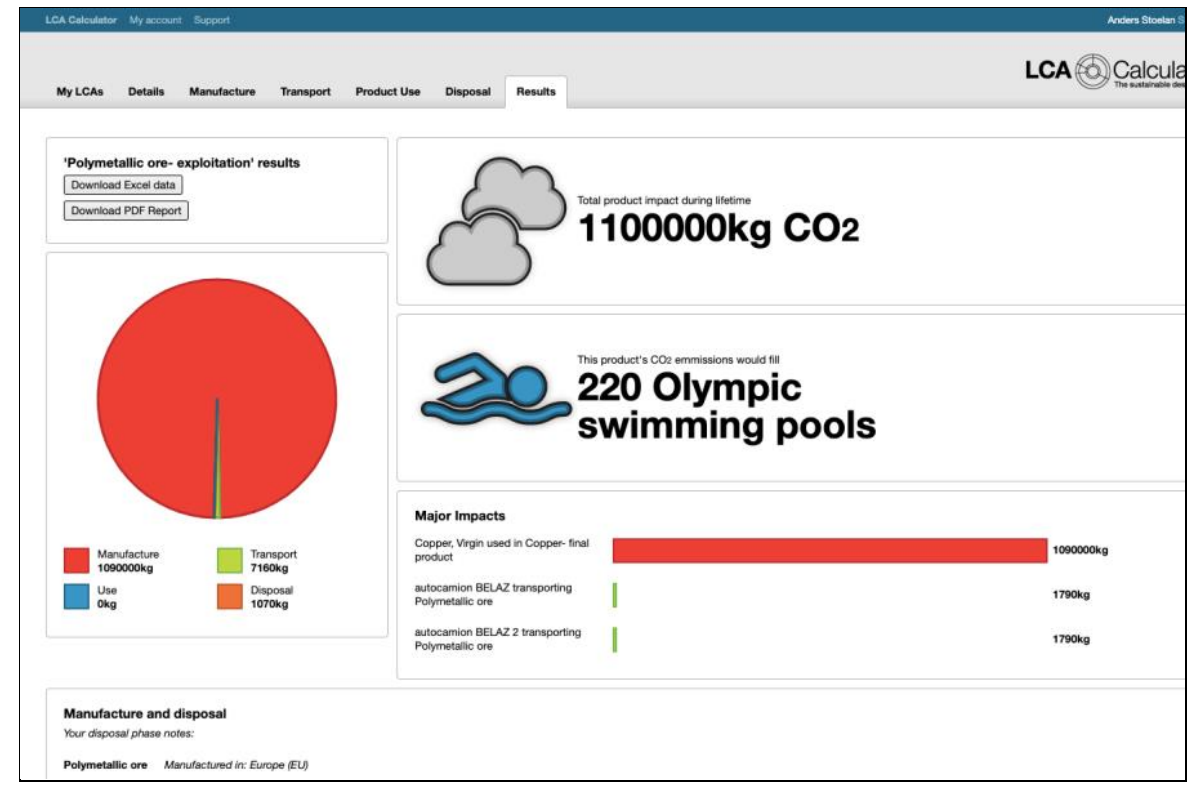

Figure 2. LCA Calculator results example (print screen)

The data considered in the table one is used for the real scenario and the ones in table 2 are used for the hypothetical scenario. A hypothetical scenario was analyzed in order to calculate the amount of emissions that can potentially be reduced if the mining preparation unit is moved away from the residential area of Iacobeni and placed within the mining perimeter Mănăila, where land and soil conditions allow for an optimal use of utilities: energy, water, infrastructure.

Table 1. Characteristics of the sites- real scenario

\begin{tabular}{|c|c|c|c|c|c|c|c|c|c|c|c|c|c|}
\hline \multicolumn{3}{|c|}{$\begin{array}{c}\text { Distance } \\
\text { from the } \\
\text { inhabited } \\
\text { areas }(\mathrm{km})\end{array}$} & \multicolumn{3}{|c|}{$\begin{array}{c}\text { Distance from } \\
\text { watercourses } \\
(\mathbf{k m})\end{array}$} & \multicolumn{4}{|c|}{$\begin{array}{c}\text { Distance from natural } \\
\text { areas }(\mathbf{k m})\end{array}$} & \multicolumn{4}{|c|}{$\begin{array}{l}\text { Distance from the } \\
\text { transport } \\
\text { infrastructure }(\mathrm{km})\end{array}$} \\
\hline MQ & IPU & OQD & $M Q$ & IPU & OQD & $M Q$ & & IPU & OQD & $M Q$ & IPU & & OQD \\
\hline 7 & 0,1 & 6 & $\begin{array}{l}\sqrt[3]{0} \\
\mathbb{J} \\
0 \\
0 \\
0 \\
0 \\
\frac{1}{\pi} \\
> \\
0 \\
0 \\
0 \\
0\end{array}$ & 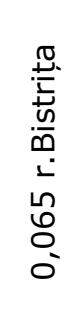 & $\begin{array}{l}\tilde{D} \\
\stackrel{0}{0} \\
0 \\
0 \\
0 \\
0\end{array}$ & 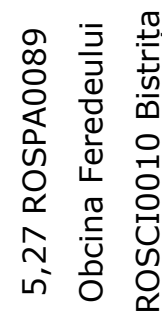 & $\frac{0}{\frac{0}{3}}$ & 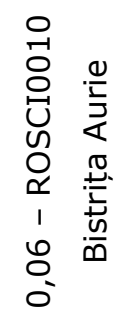 & 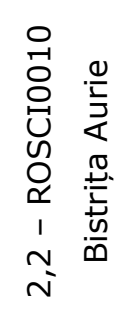 & $\begin{array}{l}\infty \\
\cdots \\
亡 \\
\vdots \\
1 \\
\infty\end{array}$ & 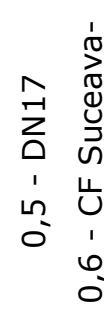 & 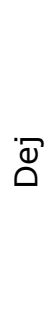 & $\begin{array}{l}\infty \\
\sum_{2} \\
0 \\
1 \\
1\end{array}$ \\
\hline
\end{tabular}


Table 2. Characteristics of the sites- hypothetical scenario

\begin{tabular}{|c|c|c|c|c|c|c|c|c|c|c|c|c|c|}
\hline \multicolumn{3}{|c|}{$\begin{array}{c}\text { Distance } \\
\text { from the } \\
\text { inhabited } \\
\text { areas }(\mathrm{km})\end{array}$} & \multicolumn{3}{|c|}{$\begin{array}{c}\text { Distance from } \\
\text { watercourses } \\
(\mathbf{k m})\end{array}$} & \multicolumn{5}{|c|}{ Distance from natural areas $(\mathbf{k m})$} & \multicolumn{3}{|c|}{$\begin{array}{c}\text { Distance from } \\
\text { the transport } \\
\text { infrastructure } \\
(\mathbf{k m})\end{array}$} \\
\hline MQ & IPU & OQD & MQ & IPU & OQD & $M Q$ & & IPU & & OQD & $M Q$ & IPU & OQD \\
\hline 7 & 7 & 6 & $\begin{array}{l}3 \pi \\
\widetilde{J} \\
\mathbb{N} \\
0 \\
0 \\
\frac{0}{\pi} \\
> \\
\dot{0} \\
\tilde{0} \\
0\end{array}$ & 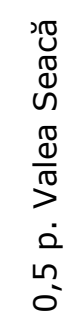 & 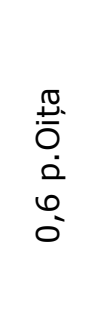 & 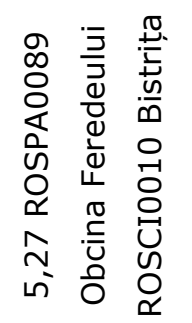 & $\frac{\mathscr{U}}{\frac{1}{3}}$ & 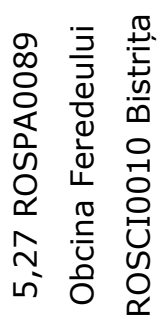 & $\frac{0}{\frac{0}{3}}$ & 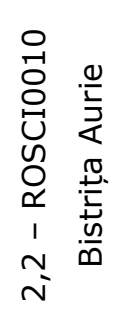 & $\begin{array}{l}\infty \\
\sum_{2} \\
0 \\
1 \\
\infty\end{array}$ & $\begin{array}{l}\infty \\
\prod_{2} \\
0 \\
1 \\
\infty\end{array}$ & $\begin{array}{l}\infty \\
\sum_{2} \\
0 \\
1 \\
1\end{array}$ \\
\hline
\end{tabular}

Abbreviations used:

- IPU: Iacobeni Preparation Unit;

- MQ: Mănăila Quarry

- OQD: Oița Quarry Dump

- MPU: Mănăila Preparation Unit

Sustainable Return on Investment (S-ROI)- is another type of methodology used in the article. It offers a more robust perspective as opposed to the "classical" return on investment approach, considering not just the economic yield, but also the societal and environmental long-term benefits. The S-ROI method "sheds light on the need to think beyond traditional life cycle cost analysis techniques that focus on direct cash benefits" (Autorizație de mediu no. 313/2012).

We analyzed and quantified the environmental, social and economic impacts by attributing the costs where possible. This is not an exhaustive analysis as only those aspects where considered, to which a monetary value could have been attributed or, such as in the case of the category Benefits, non-cash costs were considered. Since we cannot convey exact monetary values for some variables such as operating costs or maintenance costs due the limitations imposed by the data we obtained, we chose to simplify the method and use monetary units (UM) instead. One UM equals 1,000 RON.

\section{Results}

\subsection{Life Cycle Assessment Methodology}

Due to the limitations imposed by the program, we could not perform an analysis for complex composite materials, therefore our analysis relied mostly on the life cycles phase transport. The following chart shows the real scenario: 


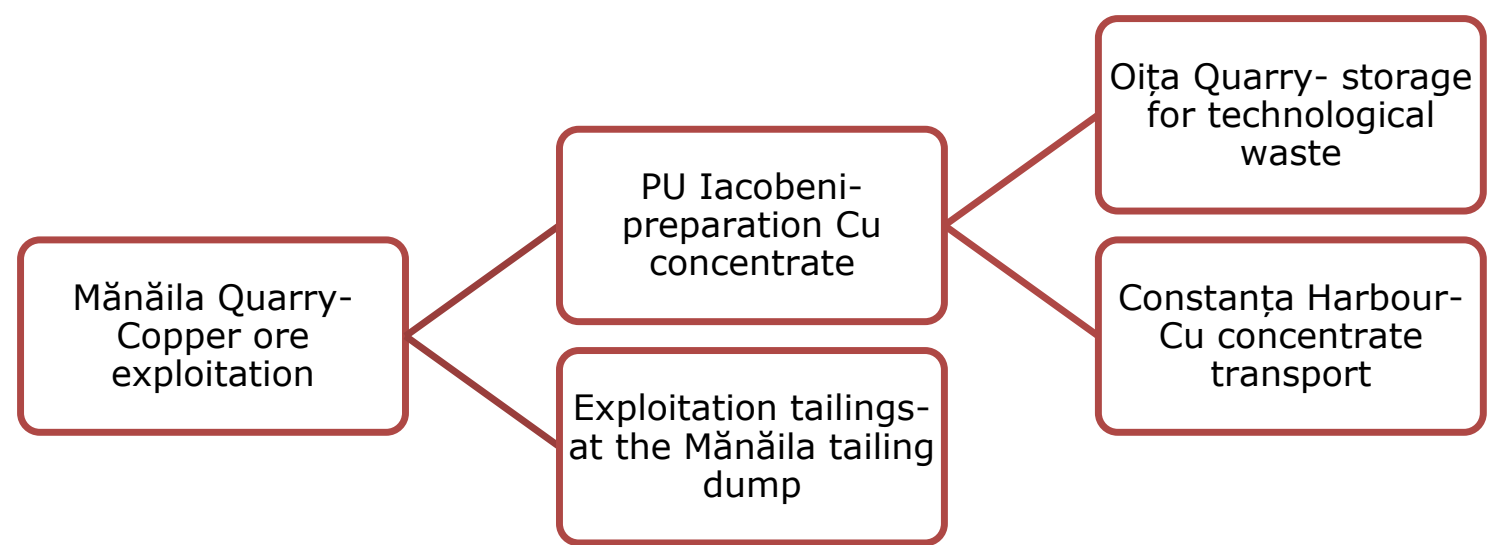

Figure 3. Real scenario- transport distances

Tabel 3. $\mathrm{CO}_{2}$ emissions in the real scenario

\begin{tabular}{cccc}
\hline \multicolumn{2}{c}{ Exploitation phase } & \multicolumn{2}{c}{ Preparation phase } \\
\hline Phase & Total $\mathrm{CO}_{2}(\mathrm{~kg})$ & Phase & Total $\mathrm{CO}_{2}(\mathrm{~kg})$ \\
Manufacture & 1090000 & Manufacture & 98100 \\
Transport & 7160 & Transport & 1850 \\
Use & 0 & Use & 0,671 \\
Disposal & 1070 & Disposal & 0 \\
Total (excl. & $\mathbf{8 2 3 0}$ & Total (excl. & $\mathbf{1 8 5 0 , 6 7 1}$ \\
Manufacture) & & Manufacture) & \\
\hline
\end{tabular}

For the hypothetical scenario we suggested moving the preparation unit to Mănăila:

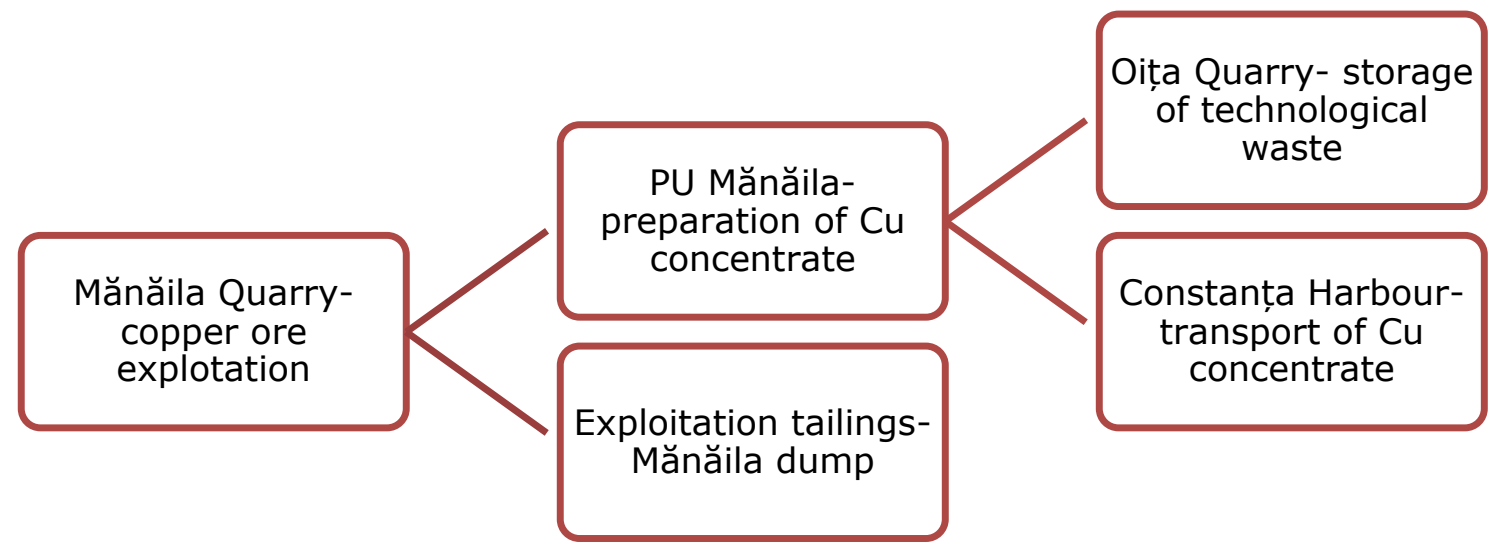

Figure 4. Hypothetical scenario - transport distances

Tabel 4. $\mathrm{CO}_{2}$ emissions in the hypothetical scenario

\begin{tabular}{cccc}
\hline \multicolumn{2}{c}{ Exploitation phase } & \multicolumn{2}{c}{ Preparation phase } \\
\hline Phase & Total $\mathrm{CO}_{2}(\mathrm{~kg})$ & Phase & Total $\mathrm{CO}_{2}(\mathrm{~kg})$ \\
Manufacture & 1090000 & Manufacture & 98100 \\
Transport & 224 & Transport & 1850 \\
Use & 0 & Use & 0,671 \\
Disposal & 1070 & Disposal & 0 \\
Total (excl. & $\mathbf{1 2 9 4}$ & Total (excl. & $\mathbf{1 8 5 0 , 6 7 1}$ \\
Manufacture) & $\mathbf{M a n u f a c t u r e )}$ & \\
\hline
\end{tabular}


By comparing the carbon dioxide quantities in the two scenarios, it becomes evident that by moving the mining preparation unit to Mănăila, in the proximity of the exploitation site, the emissions can be reduced by $68.8 \%$ (Figure 5 ).

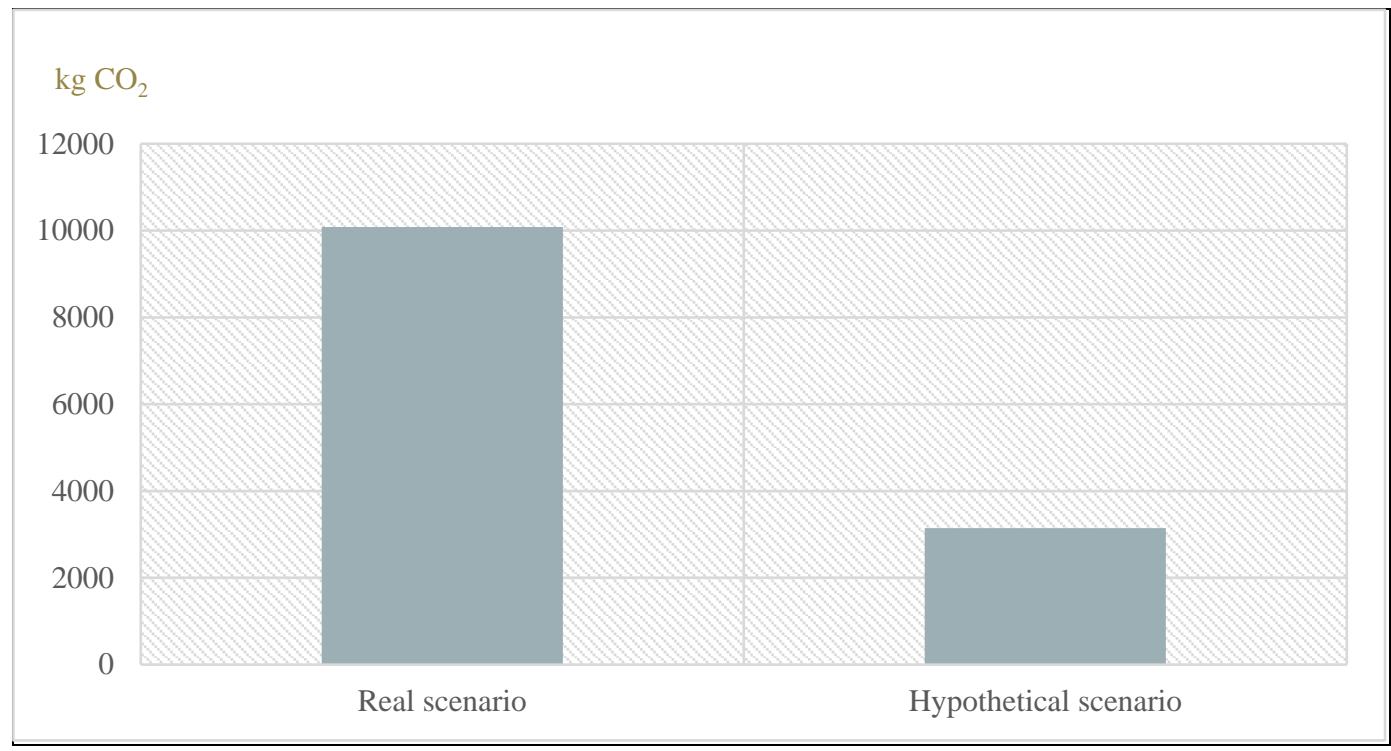

Figure 5. The emission differences between the real and hypothetical scenario

\subsection{S-ROI Methodology}

The comparative analysis of the two scenarios for the cost segment, which covers aspects concerning the economic and social impact, is presented in tables 5-7. The costs are presented for the first year, considering the decontamination of the Iacobeni preparation unit, the ecological rehabilitation of the site, the transfer of the tailings and installations to the Mănăila site, the construction of new foundations, a technological water treatment unit (a treatment unit for household waters already exists), arranging deposits for mining concentrates and other substances used in the preparation process.

Tabel 5. Direct costs

\begin{tabular}{ccccc}
\hline \multicolumn{1}{c}{ Real scenario } & \multicolumn{3}{c}{ Hypothetical scenario } \\
\hline \multicolumn{1}{c}{ Activity costs } & MU/year & \multicolumn{1}{c}{ Activity Costs } & MU/year \\
Operating and maintenences costs & 18.000 & $\begin{array}{l}\text { Operating and maintenences } \\
\text { costs }\end{array}$ & 18.000 \\
Monitoring costs & 62 & Monitoring costs & 38 \\
Ore transport from MQ to IPU & 363 & Ore transport from MQ to MPU & 10,2 \\
Decommissioning/decontamination & 1.150 & Constructions- assembly MPU & 1.400 \\
IPU & $\mathbf{1 9 . 5 7 5}$ & Total first year & $\mathbf{1 9 . 4 4 8 , 2}$ \\
$\quad$ Total first year & $\mathbf{1 9 . 4 2 5}$ & Total from year II & $\mathbf{1 8 . 0 4 8 , 2}$ \\
\hline
\end{tabular}

As it is observed in the table above, the costs are very similar in the first year. However, the difference becomes visible beginning with the second year, as the ore transport and monitoring costs drop. Since the new area does not impose any restrictive measures such as in Iacobeni (a populated area traversed by important water courses such as the Bistrița Aurie River). It is important to mention that according to the water law no. 107/1996 (republished), water is "a strategic resource for the national safety and security" (art.1, alin.1^1), which comes to support the argument in favor of the 
economic profitability of changing the location of the preparation unit from Iacobeni to Mănăila.

Tabel 6. Externals costs

\begin{tabular}{|c|c|c|c|}
\hline \multicolumn{2}{|l|}{ Real scenario } & \multicolumn{2}{|c|}{ Hypothetical scenario } \\
\hline $\begin{array}{l}\text { Activity costs } \\
\text { The households in the } \\
\text { proximity of the IPU have } \\
\text { low prices- } 7 \text { households } \\
/ 150-200 \mathrm{~m} \text { radius }\end{array}$ & 343 & $\begin{array}{l}\text { Activity costs } \\
\text { The disappearance of IPU } \\
\text { and the decontamination } \\
\text { of the area will lead to the } \\
\text { alignment of real estate } \\
\text { prices with the ones in the } \\
\text { ones in the Iacobeni village }\end{array}$ & 13.650 \\
\hline $\begin{array}{l}\text { Supplementary costs for } \\
\text { population health in the area } \\
\text { of the IPU, affected by } \\
\text { particle pollution and other } \\
\text { atmospheric pollutants } \\
\text { during the transport phase of } \\
\text { the ore, finite product and } \\
\text { waste }\end{array}$ & $\begin{array}{l}\text { IPU can be } \\
\text { summoned } \\
\text { to court for } \\
\text { damages } \\
\text { inflicted }\end{array}$ & $\begin{array}{l}\text { Costs related to the health } \\
\text { of the population drop in } \\
\text { the former area of IPU as } \\
\text { all sickness causing } \\
\text { sources are eliminated } \\
\text { (typical health problems } \\
\text { included pulmonary } \\
\text { diseases, asthma, allergies } \\
\text { etc.) }\end{array}$ & \\
\hline $\begin{array}{l}\text { Supplementary costs for } \\
\text { food- despite being an agro- } \\
\text { pastoral area, the crops lack } \\
\text { nutrition due to particle } \\
\text { pollution }\end{array}$ & $30,6 /$ month & $\begin{array}{l}\text { Reviving the agro-pastoral } \\
\text { activities in the IPU area } \\
\text { will cause food costs to } \\
\text { drop }\end{array}$ & $15 /$ month \\
\hline
\end{tabular}

Moving the Preparation Unit from Iacobeni to Mănăila makes the area more attractive from an urbanistic point of view, by maintaining the population constant. The natural environment in the area is also of special value, as it hosts natural protected areas of community importance, integrated in the European ecological network Natura 2000 such as the ROSCI0010 Bistrița Aurie, while the access to infrastructure is also optimal. The area is the home of other objectives of historical importance: the Lutheran church, administrative buildings from the end of the 18th century (belonging to the mining exploitation of Anton Mantz von Mariensee).

In order to evaluate the food costs, we considered the average monthly value of a a basket necessary for one person [16].

Tabel 7. Contingent costs

\begin{tabular}{|c|c|c|c|}
\hline \multicolumn{2}{|l|}{ Real scenario } & \multicolumn{2}{|l|}{ Hypothetical scenario } \\
\hline Activity costs & UM & Activity costs & UM \\
\hline $\begin{array}{l}\text { Pollution penalties. There are } 4 \text { main } \\
\text { situations in which the society received or } \\
\text { can receive fines (especially considering } \\
\text { the very short distance of } 65 \mathrm{~m} \text { from the } \\
\text { Bistrița River and approx. } 100 \mathrm{~m} \text { from the } \\
\text { households): wastewater discharge into } \\
\text { surface waters, storage of substances or }\end{array}$ & $\begin{array}{l}270 / \\
\text { year }\end{array}$ & $\begin{array}{l}\text { Decrease the likelihood of } \\
\text { pollution penalties, with } \\
\text { no more restricted areas } \\
\text { that could be directly } \\
\text { affected }\end{array}$ & $\begin{array}{l}80 / \\
\text { year }\end{array}$ \\
\hline
\end{tabular}


residues on the shores of the watercourses, affecting the species and habitats from ROSCI0010 Bistrița Aurie, exceeding the allowed emission limits imposed by regulatory acts

Additional systems for the containment and surveillance of air pollutants, as well as monitoring methods imposed by regulatory acts, given the positioning of UPI in the proximity of the residential area and in the immediate vicinity of the river Bistrița (with normative emission restrictions)

$26 \begin{array}{lr}\text { No } & \text { additional } \\ \text { atmospheric } & \text { pollutants } \\ \text { monitoring systems are } \\ \text { required }\end{array}$

296

The penalties for different environmental impacts were calculated as specified in the chapter Sanctions from the Emergency Government Ordinance no.195/2006 concerning environmental protection, approved with subsequent modifications and completions, according to the various types of sanctions imposed over the course of time to economic operators at the PU Iacobeni: wastewater discharge into the surface waters, storing wastes on the shores of the river, omitting to declare accidental pollution. The differences point without a doubt towards the benefits of moving the mining preparation unit from Mănăila to Iacobeni. However, a study on the dispersion of pollutants in the air around the Mănăila site is a necessity, as the area is characterized by a specific mountain climate and vulnerable forest vegetation that can easily be affected by cumulated emissions from the exploitation and preparation of copper ore.

The various aspects concerning Benefits have been qualitatively evaluated (table 8):

Tabel 8. Benefits

\begin{tabular}{|c|c|}
\hline Real scenario & Hypothetical scenario \\
\hline I. Economic benefits & \\
\hline $\begin{array}{l}\text { Facilitating access to transport } \\
\text { infrastructure in order to ship Copper } \\
\text { concentrates for supply } \\
\text { II. Social benefits }\end{array}$ & $\begin{array}{l}\text { Decrease of heavy traffic on the } \\
\text { national roads DN18 and DN } 17 \text { and } \\
\text { lower costs for ore transport }\end{array}$ \\
\hline- & $\begin{array}{l}\text { Eliminating pollution sources at the PU } \\
\text { Iacobeni will boost the quality of life } \\
\text { and will likely motivate people to } \\
\text { continue to reside in the are. }\end{array}$ \\
\hline III. Environmental benefits & \\
\hline- & $\begin{array}{l}\text { The source of direct negative impact } \\
\text { on the natural protected area of } \\
\text { community importance ROSCI0010 } \\
\text { Bistrița Aurie disappears } \\
\text { By eliminating the transport line } \\
\text { between MQ and IPU, the levels of air } \\
\text { pollutants will significantly drop on the }\end{array}$ \\
\hline
\end{tabular}


route between the communes Ciocănești and Iacobeni

The water quality in the Bistrița Aurie River will increase around the area of the PU Iacobeni site

\section{Discussion}

The complementary combination of the two methodologies used, Life Cycle Assessment and Sustainable Return on Investment is proven to be of great use in sustainable planning, both for companies and governmental policies. However, the main limitations arise from the inability to have absolute results, since both methods can be progressively accurate depending on how much data is available and how complex the software is. Companies are generally reluctant to share more than what they consider necessary, therefor the sustainability analysis becomes more relevant and more exact, the more specific the analyzed branch of activity or life cycle phase is.

Particularly in this case, the LCA methodology was based on the transport emissions, as the program we had available could not offer sufficiently accurate data on complex composite materials for the manufacturing phase. This would require a separate, indepth analysis. Nevertheless, the transport phase is more relevant as it is most likely the only life cycle phase where a company has the capacity and flexibility to make alterations from a decision-making point of view.

The S-ROI method "sheds light on the need to think beyond traditional life cycle cost analysis techniques that focus on direct cash benefits" [12]. It comes as an optimal supplement to the $L C A$ method and can be used for a very detailed cost analysis. Having both methods combined, we could identify not only the emission reductions possible from feasible and realistic changes in the transport phase and the overall social profitability resulting from moving the Preparation Unit from Iacobeni to Mănăila and keeping the same exploitation and ore preparation capacity.

\section{Conclusions}

The importance of copper in the development of human society cannot be underestimated: based on the principles of sustainable development, copper is important not only economically but also socially. It can generate sums at the level of billions of euros from its use in almost all industrial fields: energy, car manufacturing industry, infrastructure, gadgets etc. Socially, all life cycles of copper, from extraction and processing, production and use of copper-based products and all auxiliary and derived activities imply a great number of employees: miners, researchers, engineers, recyclists, medical staff, professors, artists, construction workers etc. Moreover, from an environmental point of view, copper is an important element used in renewable energy systems, it is $100 \%$ recyclable without losing its properties and can also be used on waste treatment projects.

Analyzing the ways in which the Suceava County's economic society dealing with copper exploitation and preparation can limit its impact and gradually become more sustainable, primarily by moving the Preparation Unit from Iacobeni to the Mănăila Quarry (according to our hypothetical scenario), the following aspects stand out:

- The Life Cycle Assessment of the mining activity has demonstrated for the hypothetical scenario a $68.8 \%$ drop in emissions. 
- Through the S-ROI analysis, for the hypothetical scenario the direct costs drop beginning with the second year by cca. 1377 monetary units, contingent costs drop by $300 \%$ and the benefits are net in favour of the Hypothetical scenario. Therefore, the social profitability of such an investment depends on moving the Preparation Unit from Iacobeni to Mănăila and keeping the same exploitation and ore preparation capacity.

Nevertheless, further studies are necessary to evaluate the impact of pollutants on the forest vegetation in the Mănăila area.

\section{References}

1. Awuah-Offei, K., Adekpedjou, A., (2011), Application of life cycle assessment in the mining industry, Int J Life Cycle Assessment 16; pp.82-89

2. Bichard, E. (2016), Sustainable return on investment: towards a method of valuing social and environmental change in the build environment, Article, $2^{\text {st }}$ Annual international conference on social sciences (AICSS), University of Salford, Manchester, UK

3. IRP (2020), Mineral Resource Governance in the 21st Century: Gearing extractive industries towards sustainable development. Lead authors: Ayuk, E. T., Pedro, A. M., Ekins, P., et al., A. R. D. A Report by the International Resource Panel. United Nations Environment Programme, Nairobi, Kenya.

4. Legea nr. 107/1996 (republished)

5. Memary R., Giurco,D., Mudd G., Mason L., (2012), Life cycle assessment: a time-series analysis of copper, Journal of Cleaner Production 33, pp. 97-108

6. Mudd, Gavin \& Roche, Charles \& Northey, Stephen \& Jowitt, Simon \& Gamato, Gama. (2020). Mining in Papua New Guinea: A complex story of trends, impacts and governance. Science of The Total Environment. 741. 140375. 10.1016/j.scitotenv.2020.140375.

7. Nicholls, J. (2017), Social return on investment - development and convergence, ElsevierEvaluation and Programme Planning, Vol.64, pp.127-135

8. Ordonanța de Urgență a Guvernului nr. 195/2005 privind protecția mediului aprobată cu modificări și comletări de Legea nr. 265/2006, cu modif. și compl. Ulterioare

9. Ordonanţa de urgenţă a Guvernului nr. 57/2007 privind regimul ariilor naturale protejate, conservarea habitatelor naturale, a florei şi faunei sălbatice, aprobată cu modificări şi completări prin Legea nr. 49/2011

10. SC SINAROM MINING GROUP SRL- Autorizația de mediu nr. 221/2012 pentru extracția minereului polimetalic din perimetrul Mănăila, emisă de Environmental Protaction Agency (EPA) Suceava

11. SC SINAROM MINING GROUP SRL- Autorizația de mediu nr. 272/2012 pentru Depozit de steril uzinal, emisă de EPA Suceava

12. SC SINAROM MINING GROUP SRL- Autorizația de mediu nr. 313/2012 rev.2013 pentru Uzina de Preparare a minereului polimetalic Iacobeni, emisă de EPA Suceava

13. Sonderegger, Thomas \& Dewulf, Jo \& Fantke, Peter \& Souza, Danielle Maia de \& Pfister, Stephan \& Stoessel, Franziska \& Verones, Francesca \& Vieira, Marisa \& Weidema, Bo \& Hellweg, Stefanie. (2017). Towards harmonizing natural resources as an area of protection in Life Cycle Impact Assessment. The International Journal of Life Cycle Assessment. 22. 10.1007/s11367-017-1297-8.

14. Soulier, M., Glösser- Chahoud, S., Glodmann, D., Tercero Espinoza, L.A., (2018), Dynamic analysisof European copper flows, Elsevier, vol. 129, pp.143-152

15. Williams, J.F., Parker,J. (2010), Measuring the Sustainable Return on Investment of Waste to Energy, proceding of the $18^{\text {th }}$ Annual North American Waste to Energy Conference NAWTEC 18, Orlando, Florida, USA, doi: 13.1115/NAWTEC 18-3552 
16. www.economica.net (accessed on 2/11/2020)

17. www.icsg.org- The World Copper Factbook 2020 (accessed on 10/10/2020)

18. https://copperalliance.ro/despre-cupru/ (accessed on 15/10/2020)

(C) 2021 by the authors. Licensee UAIC, Iasi, Romania. This article is an open access article distributed under the terms and conditions of the Creative Commons Attribution (CC BY-NC-ND) license (https://creativecommons.org/licenses/by-ncnd/4.0). 